\title{
Tomasz Sobieraj
}

\section{Realizm „krytyczny” i empatyczny. Modernistyczne projekty pisarskie (Prusa i innych)}

\author{
K $\begin{array}{lllllll} & \text { y } & \text { t } & y & \mathrm{~K} & \mathrm{i}\end{array}$ \\ Ewa Paczoska, Lekcje uważności. \\ Moderniści i realizm, Wydawni- \\ ctwo Naukowe PWN, Warszawa \\ 2018
}

wi nowoczesność, formacja, której poświęciła ona już wiele znakomitych, odkrywczych prac. Ważnym literackim manifestem nowoczesności okazała się - zdaniem Paczoskiej - proza realistyczna schyłku XIX i początku XX wieku, reprezentowana w jej ujęciu głównie przez twórczość Bolesława Prusa i Henry'ego Jamesa (nb. stanowiącą główny obiekt analiz w pierwszej części książki, zatytułowanej Testowanie granic), proza przekształcająca dotychczasowy model realizmu, ściśle przy tym powiązana z kategorią „uważności”. Interpretowani przez nią pisarze, kojarzeni zwyczajowo z poetyką realizmu, sytuują się ciągle w jego ramach, tyle że - jak podkreśla autorka - „wciąż, w różnych kierunkach rozszerzają jego pole i testują jego granice" (s. 15). I dalej: „Program nowego realizmu, który proponują Prus i James, zmierza od formuly «reprezentacji» do formuły «obecności»»" (s. 15). Ich poszukiwaniom artystycznym nadal wszak przyświecał „imperatyw prawdy”.

Jeden z najlepszych znawców powieści modernistycznej i postmodernistycznej, Brian McHale, charakteryzował tę pierwszą odmianę gatunku jako ukształtowaną przez dominantę

\footnotetext{
lan Watt przekonująco uzasadniał związek poetyki angielskiej powieści realistycznej z filozofią empiryzmu, nastawiona na konkret i doświadczenie jednostkowe. Zob. tegoż, Narodziny powieści. Studia o Defoe'em, Richardsonie i Fieldingu, przeł. A. Kreczmar, Warszawa 1973, rozdział I: Realizm a powieść jako forma literacka s. $5-36$.
} 
epistemologiczną. „Oznacza to - pisał - że stosuje ona strategie, które wysuwają na pierwszy plan pytania w rodzaju [...]: "Jak mam interpretować świat, którego jestem częścią? I czym w tym świecie jestem?» [...]. Można też dodać inne pytania, również typowo modernistyczne: «Co należy poznać? Kto poznaje? Jak oni to poznają i jak bardzo są tego pewni? Jak przekazywana jest wiedza między ludźmi i jak bardzo jest ona rzetelna? Jak zmienia się przedmiot poznania, gdy przechodzi od jednej osoby poznającej do drugiej? Gdzie leżą granice tego, co poznawalne?»"2.

Wydaje się, że podobne (lub wręcz tożsame) zagadnienia epistemologiczne formowały struktury „nowego” realizmu w prozie Prusa, Jamesa, a także Stanisława Brzozowskiego oraz Virginii Woolf, bohaterki dwóch szkiców zamieszczonych przez Paczoską w drugiej części jej monografii, zatytułowanej Poszerzanie obszaru. Interpretacje poszczególnych utworów oraz myśli teoretycznoliterackiej pisarzy oscylują tu wokół hipotezy nieciągłości, chaotyczności lub wręcz rozpadu świata. Warto wspomnieć, że już w połowie lat dziewięćdziesiątych autorka ogłosiła ważną książkę o Lalce ${ }^{3}$, w której formułę tę wykorzystała do błyskotliwej egzegezy powieści, ustanawiając ważny, wielokrotnie odtąd wykorzystywany i rozwijany, trop interpretacyjny.

Realizm Prusa, Jamesa, Brzozowskiego, Woolf został przez autorkę zdefiniowany jako estetyka zdeterminowana przez odczucie kryzysu kulturowego nowoczesności, oddziałującego na formy reprezentacji literackiej, modus bohatera i wreszcie na struktury narracyjne oraz kompozycje fabularne powieści. Paczoska przeprowadziła na przykład komparatystyczną interpretację Lalki Prusa i powieści Ame-

\footnotetext{
${ }^{2}$ B. McHale, Powieść postmodernistyczna, przeł. M. Płaza, Kraków 2012, s. 13.

${ }^{3}$ Zob. E. Paczoska, „Lalka”, czyli rozpad świata, Białystok 1995 (wyd. 2 Warszawa 2008).
}

rykanin Henry'ego Jamesa, odkrywając dużo zbieżności i podobieństw między wyobraźnią artystyczną obu pisarzy, rzutujących na format protagonistów oraz ich doświadczeń miłosnych i społecznych. Kryzys idealizmu (życiowego) naznaczył - jej zdaniem - sensy globalne obu powieści. „W świecie dotkniętym nowoczesną zmianą - pisała - romantyczny z ducha (ale i romansowy na wzór marzeń pani Bovary) idealizm buduje anachroniczne i dysfunkcjonalne fantazmaty, które nie pozwalają swoim wyznawcom na prawdziwy rozwój, blokują ich energię, wreszcie - nie pozwalają ujawnić się instynktom i uczuciom" (s. 61-62).

Manifestem poszukiwania kompleksowej realności życia uczyniła autorka twórczość artystyczną i krytyczną Virginii Woolf, odnajdującej własną antenatkę w osobie Jane Austen. Teoria powieści Woolf oraz jej przekonania metafizyczne dotyczące istnienia zostały przez Paczoską precyzyjnie uchwycone, sama zaś pisarka - konfrontowana z Austen - jawi się jako krytyczka niezwykle świadoma reguł własnej twórczości oraz doskonale zorientowana w poetyce swojej wielkiej poprzedniczki. Swój sprzeciw wobec tradycyjnego realizmu (charakterystycznego np. dla utworów Galsworthy'ego) motywowała pisarka dążeniem do uchwycenia pełnej realności, a więc chęcią stworzenia powieści prawdziwie realistycznej, niezafałszowanej konwencjami literackimi oraz poznawczymi schematami. Powieść taka ukazywałaby związek drobiazgu i konkretu z autentyczną egzystencją, zawierała niepozorne momenty epifanijne, owe - przywołane przez Woolf w Do latarni morskiej - „krople jasności”, w których na chwilę rozbłyska rzeczywistość niedająca się pochwycić całościowo.

Można by w analizowanej przez Paczoską prozie wczesnomodernistycznej odnaleźć przejawy realizmu „krytycznego”, przeciwstawionego wcześniejszym, skodyfikowanym w pierwszej połowie XIX wieku (głównie w twórczości 
Balzaka, ale także np. Dickensa), odmianom realizmu „naiwnego” (prezentacjonistycznego), który nie problematyzował ani statusu rzeczywistości, ani bohatera, uznając powieściowe artefakty - zgodnie z zasadą referencji bezpośredniej - za odtworzenie świata istniejącego obiektywnie (poza dziełem literackim). Mimesis krytyczna zasadzałaby się z kolei na podawaniu w wątpliwość statusu zarówno rzeczywistości przedstawionej w utworze, jak i samych bohaterów, a także sposobów jej poznawania przez narratora i/lub bohatera ${ }^{4}$. Rzecz jasna, ta druga kwestia wiązała się już z perspektywizmem poznawczym albo, inaczej rzecz ujmując, z techniką punktu widzenia, teoretycznie opracowaną i praktycznie realizowaną przez Henry'ego Jamesa, Bolesława Prusa i wielu innych powieściopisarzy wczesnego modernizmu. Paczoska przekonująco udowodniła, że i Prus, i James wyróżniali się „niezwykle wysoką świadomością”, wszakże „każdy z nich poświęca kwestiom mechaniki powieściowej oddzielne i dogłębne refleksje" (s. 75). To trafne rozpoznanie, ujawniające kontekst nieobecny dotąd w pracach poświęconych Prusowskiej teorii powieści (i literatury), które akcentowały związki polskiego pisarza z innymi twórcami i tradycjami.

Autorka przekonuje nadto, iż w modelu realizmu powieści wczesnomodernistycznej Prusa i Jamesa kluczową rolę odgrywała także nowa koncepcja antropologiczna - „człowieka psychologicznego" (termin ukuty przez polskiego pisarza) (s. 76). W koncepcji tej skumulowały się różnorodne czynniki, ona sama zaś stano-

\footnotetext{
${ }^{4}$ Zaproponowana tu - zresztą w trybie operacyjnym - definicja realizmu „krytycznego” czy też mimesis krytycznej nie pokrywa się w całości z tym, co w 2007 roku zaproponował Jerzy Franczak, który napisał: „można [...] powiedzieć, że mimesis tradycyjna opierała się na przekonaniu, iż doświadczenie jest ze swej natury wysławialne. Mimesis krytyczna, zamiast powielać oferowane przez kulturę scenariusze, dąży do ukazania jej nomenklatury, do opisania mechanizmu reprodukcji zastanego doświadczenia językowego". J. Franczak, Poszukiwanie realności. Światopogląd polskiej prozy modernistycznej, Kraków 2007, s. 49.
}

wiła korelat poszukiwań twórców zmierzających do odkrywania prawdy autentycznego doświadczenia. Struktury poznawcze „człowieka psychologicznego" nie tworzyły już fundamentu pod prawdę obiektywną, stały się bowiem pozycjami zrelatywizowanymi, poddanymi działaniu rozmaitych czynników determinujących, w tym także treści nieświadomości. Bohaterowie „sformatowani” według koncepcji „człowieka psychologicznego" funkcjonowali w świecie coraz bardziej heterogenicznym, konfrontującym ze sobą wiele stanowisk poznawczych i emotywnych, pozbawionym zaś nadrzednej perspektywy scalającej sens globalny powieści w koherentną całość. Taką formułe „realizmu empatycznego", by przywołać termin Paczoskiej ${ }^{5}$, realizmu, który skupiał się na eksploracji podmiotowych uczuć, doznań i myśli protagonisty doświadczającego świat na sposób solipsystyczny, realizowała z pewnością Lalka Prusa. Jeśli idzie o Emancypantki, to rzecz wyglądała inaczej z uwagi na wprowadzoną przez Prusa korektę światopoglądową w postaci silnej tezy metafizycznej. Wspomniana formuła przejawiała się też, rzecz jasna, w wielu powieściach Henry'ego Jamesa.

Obcując z interpretacjami realizmu „krytycznego" dwóch głównych bohaterów monografii, chciałoby się niekiedy uchwycić autorskie rozumienie kategorii „rzeczywistości”, która niestety nie jest objaśniona i funkcjonuje raczej na zasadzie presupozycji. Z rozważań Paczoskiej można wywieść wniosek, że metafizyczne poglądy Prusa, Brzozowskiego, Jamesa i innych nie zrewolucjonizowały jednak hipotezy realistycznej. To znaczy: autorzy ci zakładali, iż rzeczywistość, której dostępność w procesie poznawczym znacząco się wprawdzie sprob-

\footnotetext{
${ }^{5}$ Paczoska stwierdziła: „Powieść w wydaniu Jamesa i Prusa dałoby się na pewno umieścić w formule "realizmu empatycznego", czyli nastawionego na sposób odczuwania świata przez bohaterów, gdzie oko kamery skierowane jest na sferę wrażeń, uczuć, relacji między tym, co ukrywane, i tym, co manifestowane" (s. 76, wyróżnienia autorki).
} 
lematyzowała, istnieje wszak niezależnie od podmiotu. Nieobecność tej problematyki wynikła tu ze świadomego autorskiego założenia; monografia po prostu koncentruje się na innych perspektywach realizmu.

Za najważniejszą merytoryczną zaletę monografii Lekcje uważności uznałbym podjętą i konsekwentnie przez autorkę realizowaną próbę „zmodernizowania” realizmu Prusa i innych omawianych w niej pisarzy. Ewa Paczoska twórczo rozwinęła tu swoje niegdysiejsze rozpoznania, (re)konstruując poetykę i światopogląd powieści realistycznej przełomu XIX i XX wieku jako bodaj najważniejszej artystycznej emanacji nowoczesności.

Powieść ta wprowadziła istotne przekształcenia w panującym dotąd modelu realizmu. Można by ogólnie stwierdzić, iż obraz świata stał się w niej poznawczo nieprzenikniony, skomplikowany, złożony, nawet chaotyczny. Przemianom uległa także, jak już wcześniej zauważono, koncepcja podmiotowości, co uwidoczniło się i w konstrukcji narracji, i w profilach protagonistów. W końcowym fragmencie rozdziału Empatia i ironia. Bolesława Prusa i Henry'ego Jamesa gry z powieścią wiktoriańską, oceniając grę iluzji i deziluzji w fabułach obu pisarzy, autorka stwierdziła: „W Lalce czy Ambasadorach nie tylko [...] odsłania pomyłki czy błędy poznawcze bohaterów wynikające z niedostatecznej wiedzy lub ze stosowanych przez nich stereotypów poznawczych, lecz także pokazuje ogólną skłonność ludzkiego umysłu do łatwych fabuł, sensacyjnych wątków, domkniętych zakończeń, do łatwej kwalifikacji niejednoznacznych przecież wydarzeń życia. Wiedzie to do dekonstrukcji realizmu typu dickensowskiego" (s. 80).

Za istotny komponent „krytycznego” (oraz empatycznego) realizmu powieści Prusa i Jamesa uznała Paczoska dramatyzację, przy czym nie traktowała jej jako dobrze już rozpoznanego wyznacznika prozy modernistycznej. Ta drama- tyzacja, kształtująca "nową formułę realizmu”, to „ważny pomysł konstrukcji powieściowej” (s. 87), oddziałujący na strukturę świata przedstawionego, która nabiera dynamiki, stając się konfrontacją i grą znaczeń bezpośrednio angażującą doświadczenia bohaterów. Paczoska widzi też w owej dramatyzacji (zresztą w ślad za Richardem Shustermanem ${ }^{6}$ ) wyrazistą ramę skupiającą i intensyfikującą substancję danego zdarzenia lub doświadczenia. Tym sposobem dramatyzacja byłaby środkiem ku osiągnięciu realności przesłoniętej przez rozmaite mistyfikacje poznawcze oraz konwencje literackie. Świat powieściowy zaś nabierałby cech płynności, a bohaterowie musieliby odkrywać prawdę o nim oraz o sobie w toku działań, zdarzeń, konfrontacji. „Substancjalizacja realności”, osiągana dzięki technice dramatyzacji, oznaczała już - jak dowodzi Paczoska - nowy, częściowy zmodyfikowany model realizmu powieściowego, niezrywający jeszcze całkowicie, rzecz jasna, związków z tradycją dziewiętnastowiecznej mimesis, ale nastawiony m.in. na odkrywczą eksplorację ludzkiego wnętrza oraz psychicznych doznań i doświadczeń bohaterów (s. 96).

Traktowanie powieści jako „ważnego zadania poznawczego", które podejmować musiał zarówno autor, jak i czytelnik, sytuowałoby Prusa i Jamesa w ścisłym kregu modernizmu. Pakt reprezentacji, stanowiący paradygmatyczny wyróżnik estetyki mimesis i - tym samym - powieści realistycznej, uległ w praktykach twórczych obu powieściopisarzy częściowej kontestacji. Świadczyło o niej m.in. przekonanie o niepełnej poznawalności świata zewnętrznego i wewnętrznego. Prus jako autor Lalki zbliżał się do agnostycyzmu poznawczego, niekiedy wręcz

\footnotetext{
${ }^{6}$ Chodzi tu o esej krytyczny Art as Dramatization, zamieszczony w książce Shustermana Surface and Depth: Dialectics Critics and Culture, Cornell University Press 2002, w polskim tłumaczeniu Wojciecha Małeckiego wydany w zbiorze autora pt. O sztuce i życiu: od poetyki hip-hopu do filozofii somatycznej, wybór, opracowanie i tłumaczenie tekstów W. Małecki, współpraca naukowa A. Chmielewski, Wrocław 2007.
} 
ocierał o sceptycyzm, z kolei James problematyzował sam sposób tworzenia opowieści, wypróbowując, by tak rzec, różne jej możliwości (s. 113-114).

Ważną propozycją syntezy interpretacyjnej jest w monografii studium poświęcone ewolucji polskiej prozy dziewiętnastowiecznej widzianej przez pryzmat związków z wiktorianizmem. Autorka przekonująco - i pioniersko - udowodniła istnienie zarówno ideowych, jak i artystycznych podobieństw między literaturą polską a angielską, które pomimo odmiennych kontekstów politycznych rozwijały się w sposób porównywalny, co dowodnie świadczyło o tożsamości kulturowej formacji dziewiętnastowiecznej w całej Europie. Emocjonalne umiarkowanie, prymat obowiązków społecznych nad aspiracjami indywidualnymi, praca jako powołanie człowieka i kryterium jego wartości moralnej, idee etycznego utylitaryzmu - to wszystko składało się na światopoglądowe oblicze prozy polskiej i wiktoriańskiej. Wśród wymienionych przez Paczoską wielkich postaci kultury wiktoriańskich inspirujących polskich twórców zabrakło jednak Karola Darwina, którego wpływ na światopoglądy pisarzy dawno już przecież rozpoznano ${ }^{7}$. Wiktorianizm stał się wyrazistą emanacją duchowości dziewiętnastowiecznej, w literaturze zaś powieściowej uzasadniał niejako pakt reprezentacji. Wyłomy w tym pakcie oznaczały też zerwanie z pryncypiami ideowymi wiktorianizmu, co autorka trafnie odnotowuje w zakończeniu szkicu.

Szczególnym przypadkiem dialogu polsko-angielskiego, który rozwinął się na początku XX stulecia był - zdaniem Paczoskiej - potencjalny kontakt Irzykowskiego z Virginią Woolf, odwzorowujący ewolucje powieści modernistycznej. Ten znakomity szkic pokazuje wszystkie kompetencje badaczki: jej rozległą orientację

\footnotetext{
Zob. np. G. Levine, Darwin and the Novelists. Patterns of Science in Victorian Fiction, London-Chicago 1992 (wyd. I - 1988 rok).
}

w przestrzeni nowoczesnej świadomości literackiej, zdolność tworzenia relacji komparatystycznych, hermeneutyczny polot i umiejętność aplikacji nowszych teorii i pojęć do historycznoliterackiej „empirii”. Tutaj skonfrontowała ona ze sobą Pałube Irzykowskiego oraz wczesną powieść Woolf Noc i dzień, powstałą w 1919 roku. Można by stwierdzić, że badaczka rozpatruje poetyki i światopoglądy obu tych powieści jako przykłady realizmu „krytycznego”, a więc takiej strategii poznawczo-artystycznej, która, powtórzmy, podawała w wątpliwość zarówno stabilną tożsamość podmiotu oraz relacji interpersonalnych, jak i status ontologiczny świata zewnętrznego. Ten nowy realizm Irzykowskiego i Woolf odrzucał tradycyjne, dziewiętnastowieczne formy estetyki mimesis. Pisarze ci przeformułowali rozumienie rzeczywistości, opowiadając się za „lekcją uważności” w stosunku do życia w całym jego chaosie, płynności i skomplikowaniu. Rzeczywistość tę oboje pragnęli pochwycić in statu nascendi, co wymagało nowych sposobów powieściowego opisu i analizy psychologicznej. Artystyczne oblicze tej rzeczywistości straciło już niegdysiejszą - znamienną dla poetyki realizmu dziewiętnastowiecznego przejrzystość i jednoznaczność, ona sama bowiem nieustannie wymykała się pojęciowemu opanowaniu, była strukturą złożoną, tajemniczą i do końca nieprzeniknioną. Modernistyczni powieściopisarze, adepci realizmu „krytycznego” i zarazem „empatycznego”, komplikowali tedy i nadawali cech wieloznaczności światom przez siebie kreowanym, orientując się coraz konsekwentniej na wnikanie w jednostkowe ludzkie doświadczenie. Świetnym potwierdzeniem tej hipotezy badawczej jest ostatni szkic drugiej części książki Paczoskiej, poświęcony opublikowanej dopiero niedawno - pisanej w latach pięćdziesiątych i sześćdziesiątych ubiegłego wieku - Powieści pod różą Jerzego Kornackiego i Heleny Boguszewskiej, współzałożycieli znanej międzywojennej grupy literackiej „Przedmieście", propagującej w międzywojniu realizm zaangażowany. 
W podsumowaniu monografii Paczoska interesująco rozpatruje położenie „realizmu” w literaturze i sztuce współczesnej. Sądzi ona, że jego obecność - rzecz jasna, w odmiennej formie niż półtora wieku temu - stanowi niezbywalny składnik literackiej komunikacji. Niewykluczone, że realizm na powrót stanie się (?) wehikułem doświadczenia jednostkowego i społecznego i najskuteczniejszym sposobem odzyskiwania prawdy, oczywiście już nie uniwersalnej i intersubiektywnej, lecz - podobnie jak w modernizmie początku XX wieku - skontekstualizowanej i perspektywicznej. Dokonane przez Paczoską rozpoznania utworów modernistów polskich i obcych tworzacych w dobie nowoczesności ów proces restytucji i redefinicji realizmu potwierdzają. Ponadto moge one - owe rozpoznania - działać jako katalizator dalszych badań nad przekształceniami powieści modernistycznej pierwszej połowy XX wieku. 


\title{
SEOWA KLUCZOWE:
}

nowoczesność

\section{REALIZM}

doświadczenie

\begin{abstract}
ABSTRAKT:
Recenzja dotyczy monografii Ewy Paczoskiej Lekcja uważności. Moderniści i realizm (Warszawa 2018), która stanowi nowatorską próbę interpretacji nowego modelu realizmu w polskiej i obcej prozie przełomu XIX i XX wieku, stanowiącej ważne stadium w rozwoju kultury i literatury nowoczesnej. Autorka wnikliwie przedstawiła proces zmian, jakim podlegało w powieści (wczesno)modernistycznej rozumienie rzeczywistości oraz sposobów jej (re)konstruowania w tekście. Krytycyzm i empatia wyznaczały - zdaniem Paczoskiej - strategie poznawcze i twórcze ówczesnych powieściopisarzy. Głównymi bohaterami rozprawy są Bolesław Prus, Henry James i Virginia Woolf, autorzy, których zarówno twórczość, jak i świadomość poetologiczna torowały drogi rozwoju powieści modernistycznej w XX wieku.
\end{abstract}




\section{empatia}

$$
\text { krytycyzm }
$$

\section{NOTA O AUTORzE:}

Tomasz Sobieraj - profesor w Instytucie Filologii Polskiej UAM, historyk literatury i kultury okresu pozytywizmu i Młodej Polski. Ostatnie publikacje: Stanisław Brzozowski. Przybliżenia (2016); Między konwencjq a innowacjq. Szkice o polskim dramacie i teatrze drugiej połowy XIX i poczatku XX wieku (2018), edycja krytyczna Emancypantek Bolesława Prusa (vol. 1, 2015; vol. 2, 2017). | 